\title{
Angular pregnancy
}

\section{Açısal gebelik}

\author{
İbrahim Alanbay1, Mustafa Öztürk², Kazım Emre Karaşahin1, Müfit Cemal Yenen1 \\ ${ }^{1}$ Gülhane Military Medical Academy, Department of Gynecology and Obstetrics, Ankara, Turkey \\ ${ }^{2}$ Etimesgut Sait Ertürk State Hospital, Clinic of Gynecology and Obstetrics, Ankara, Turkey
}

\begin{abstract}
Angular pregnancy is a rare condition in which the embryo is implanted in the lateral angle of the uterine cavity, medial to the uterotubal junction and round ligament, and causes life-threatening obstetric complications. It is important to differentiate this condition from interstitial and cornual pregnancy because they all result in emergency conditions. Although angular pregnancy can progress to term pregnancy, it may be associated with major obstetric complications such as uterine rupture, placental retention, postpartum hemorrhage, or may need further surgery and hysterectomy. This report describes a case of angular pregnancy from the $6^{\text {th }}$ gestational week and continued until delivery in the $32^{\text {nd }}$ gestational week. Sonographic findings, follow-up, and delivery concerns are described in this manuscript.
\end{abstract}

Keywords: Angular pregnancy, cornual pregnancy, ectopic pregnancy, antenatal hemorrhage, postpartum hemorrhage

$\ddot{O} z$

Açısal gebelik, embriyonun uterin kavitenin lateral açısına, medyal uterotubal bölgeden raund ligamente doğru, yerleşen ve hayatı tehdit eden obstetrik komplikasyondur. İnterstisyel gebelik ve kornual gebelik ayıııı tanısı önemlidir, çünkü bunların hepsi acil durumla sonuçlanır. Açısal gebelikler term gebeliğe kadar ilerliyebilmesine rağmen, uterin rüptür, plasental retansiyon, postpartum kanama veya histerektomiye kadar gidebilecek cerrahi yöntemlerle sonuçlanabilecek major obstetrik komplikasyonlara yol açabilir. Bu olguda gebeliğin 6 . haftasında tanı almış ve 32. haftada doğumuna kadar takip edilmiş açısal gebelik anlatılmıştır. Çalışmamızda ultrasonografi bulguları, takip ve doğum bilgileri anlatılmıştır.

Anahtar Kelimeler: Açısal gebelik, kornual gebelik, ektopik gebelik, antenatal kanama, postpartum kanama

\section{Introduction}

Angular pregnancy was first defined in 1898 by the American obstetrician Howard Kelly as implantation of the embryo just medial to the uterotubal junction, in the lateral angle of the uterine cavity $(1,2)$. Angular pregnancy is distinguished from interstitial pregnancy by embryoposition where lateral uterine enlargement of an angular pregnancy displaces the round ligament upward and outward, whereas interstitial tubal pregnancy is located lateral to the round ligament $(1)$. No absolute anatomic boundaries distinguish angular pregnancies from normal pregnancies, but the closer the location to the lateral angle of the uterus, the more it may cause visual asymmetry, symptoms, and adverse events when the pregnancy progresses (3).

Angular pregnancy is potentially dangerous and may lead to complications during pregnancy and delivery, such as persistent pelvic pain and bleeding, spontaneous abortion, uterine rupture, retained placenta, placenta accreta, and severe bleeding leading to hysterectomy $(1,4,5)$. Diagnosis is difficult, many cases may actually go undiagnosed. To the best of our knowledge, no reports have delineated the entire natural course of angular pregnancy from early diagnosis to delivery. We aimed to discuss the possible outcomes of an angular pregnancy and highlight the problems encounered during follow-up.

\section{Case Report}

A woman aged 34 years with a prior cesarean delivery, without symptoms, was admitted for a routine first antenatal examination in her $6^{\text {th }}$ gestational week. Endovaginal sonography showed a gestational sac located in the right lateral angle of the uterine cavity. The gestational sac was covered by endometrium of the medial aspect of the uterotubal junction, and the endometrial thickness was continuous with central endometrial lining (Figure 1A, B, C). We informed the patient about possible the diagnoses, natural courses, and complications. After discussing the risks, the patient requested to continue the pregnancy and close follow-up was decided. She presented with slight but

Address for Correspondence/Yazışma Adresi: Mustafa Öztürk, MD,

Etimesgut Sait Ertürk State Hospital, Clinic of Gynecology and Obstetrics, Ankara, Turkey

Phone: +90 31224910 11-3692 E-mail: drmozturk@gmail.com

Received /Geliş Tarihi: 02.04.2016 Accepted/Kabul Tarihi: 21.07.2016

${ }^{\circ}$ Copyright 2016 by Turkish Society of Obstetrics and Gynecology

Turkish Journal of Obstetrics and Gynecology published by Galenos Yaymevi. 
disturbing abdominal pain and intermittent vaginal bleeding at 9 weeks. Sonography revealed a gestational sac in the right uterine angle, which was continuing to grow towards the cavity (Figure 1D). However, the uterine growth was asymmetrical. Vaginal spotting resolved after 2 weeks. The pregnancy's development towards the uterine cavity continued, the base of the placenta was located in the right uterine angle (Figure 2A). The patient was admitted to the hospital at 27 weeks' gestation because of vaginal bleeding and mild uterine contractions. Sonography revealed a 9x4 $\mathrm{cm}$ subcorionic hematoma, anterior and next to the edge of the placenta (Figure 2B). There was no placental abruption. Tocolysis was initiated and antenatal corticosteroid was given because the fetus was immature. The hematoma areas were stabilized aboutfor 5 weeks.

Intermittent vaginal bleeding continued. Fetal biometry continued to progress appropriate to the gestational week. A cesarean section was performed at 32 weeks of gestation because of uterine contractions and dilatation of the cervix. A 1650-g female fetus was delivered. The uterus was seen asymetrically enlarged, the right uterine angle region was bulging. Upon exteriorizing the uterus, a 9x9 $\mathrm{cm}$ sacculation was seen (Figure $2 \mathrm{C}, \mathrm{D})$. The vessels were excessive and the area was bluishly discolored due to the placental location. The placenta was delivered manually and with difficulty. This area was very thin and lacking myometrial tissue, as confirmed by intrauterine and extrauterine palpation. Due to the continuation of bleeding, 3
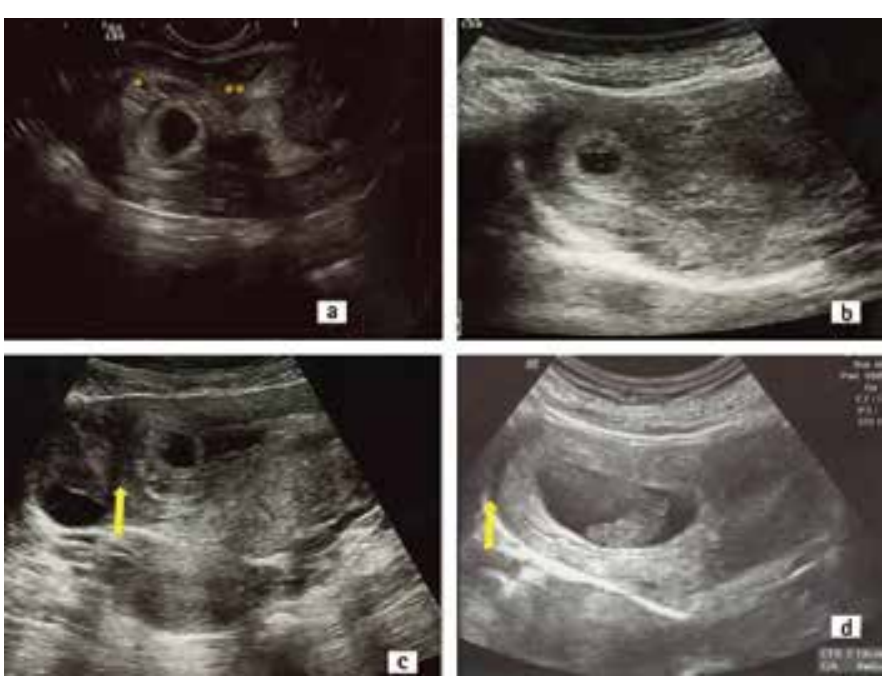

Figure 1. A) Transvaginal ultrasound view of the gestation sac at 6 weeks' gestation. The sac is covered by the endometrium (*) and continuous with the intracavitary endometrial lining $(* *), \mathrm{B})$ Transabdominal ultrasound image of the angular pregnancy at 6 weeks' gestation. The gestational sac is located in the right lateral side of the uterus. The myometrium surrounding the sac is thick and the uterus is asymmetric C) The gestastional sac growing towards the cavity at the 7 th week, the ovary is seen lateral to the arrow. Note the thickness of the myometrium around the sac. D) Transabdominal ultrasound image of the angular pregnancy at $8+6$ weeks' gestation. The asymmetric uterine enlargement is distinct square compression sutures with absorbable 0 poliglecaprone were placed passing anterior to the posterior uterine wall where the bleeding was intense. Myometrial contraction was accomplished. Obliteration of this saccular area was confirmed through intrauterine digital examination. The surgery was completed without any further complications. Bleeding was not observed, and the patient was discharged after $72 \mathrm{~h}$.

\section{Discussion}

Angular pregnancy is a rare and life-threatening obstetric complication in which the embryo is implanted in the lateral angle of the uterine cavity medial to the uterotubal junction and round ligament(1). Contrary to interstistial pregnancy, which locate in the muscular layer of the origin of tuba uterina and surrounded by myometrial layer, in angular pregnancy the embryo locates in the lateral wall endometrial thickness of the uterus $(6,7)$. The surrounding endometrial tissue of embryo is continuous with the intracavitary endometrial line. A strict distinction between these three conditions is clinically important, because their findings, management, and outcomes are different $(7)$. Interstitial pregnancy may progress without symptoms until inevitable rupture occurs at 12 -16 weeks $(6,7)$. Cornual pregnancy refers to a pregnancy in a rudimentary horn of a septate or bicornuate uterus(6). In angular pregnancy, the embryo may abort or develop in the uterine cavity(1). In contrast to interstitial pregnancy, angular pregnancy can progress to term $(1,4)$. If a patient presents at an advanced gestational age, the physician should suspect angular pregnancy if thickened placenta is located in an asymmetrically confined area of the uterine angle(3). In the second and third trimester, the placenta
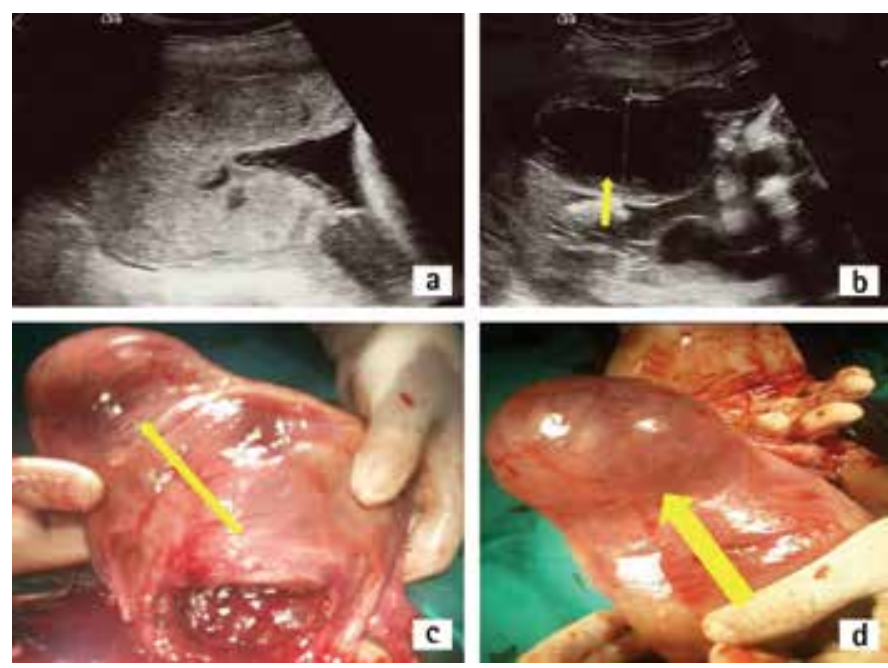

Figure 2. A) At 26 weeks' gestational age, sonogram revealed a thickened and confined placenta at the right uterine angle B) Subchorionic hematoma at the placental edge C) Photograph of the angular pregnancy, anterior view of the uterus. The right cornual area protrudes as a sacculation. The uterus is distinctly asymetric D) The view of the posterior and right lateral side of the uterus. The area is discolored due to excessive vessel formation 
may be seen limited to the uterine angle. Contrary to the normal placental growth pattern, the placenta of angular pregnancy must adopt a rigid uterine angle shape. In our opinion, the asymmetric appearance of the uterus, non-vertex fetal presentation, thickened placenta, placental adhesion anomalies, and muscular weakness of the area resulting from placental growth in the restricted, rather sharp edges of the uterine angle. This asymmetry can be seen and palpated in a thin patient in an abdominal examination. It is difficult to diagnose an angular pregnancy with certainty and to differentiate them from other abnormal implantations using ultrasound, because the main anatomic landmark (round ligament) is not visualized with this technique(6). However, angular pregnancy can be accurately diagnosed with endovaginal sonography, especially during early gestational weeks. Alternatively, 3-D ultrasound and magnetic resonance exams can facilitate diagnosis, reduce the possibility of diagnosis failure, evaluate placenta implantation anomalies, and predict the risk of uterine rupture $(3,4,6,8)$. However, when magnetic resonance is not available, we believe that the most useful approach for an exact diagnosis is sequential ultrasound evaluations to determine whether the gestational growth is towards the uterine cavity. Angular pregnancies either terminate spontaneously or proceed to term. Even spontaneous termination might be complicated by improper separation of the placenta. A full-term delivery is likely if the gestational sac descends into the uterine cavity $(1,4)$. Jansen and Elliott $(1)$ reviewed 39 cases of suspected angular pregnancies and reported that 38.5\% (10 of 26) had spontaneous or missed abortions, and $13.6 \%$ (3 of 22) had uterine ruptures. Recurrent bleeding can continue throughout pregnacy. The increased risk of preterm delivery, placental abruption, growth restriction, and postpartum endometritis is associated with angular pregnancy $(3,8)$. Abnormal fetal position can be seen, as our case was always in the breech presentation. Potential disadvantages of expectant management may include catastrophic complications such as uterine rupture. This management can be chosen by patient decision. It is necessary to counsel patients about the possible complications and close monitoring and frequent ultrasound examination should be conducted. What complicates the decision for expectant management is that there are no early sonographic signs to establish prognostic factors, although the risk of adverse outcomes can be expected to be higher when the degree of asymmetry of the protrusion at the angle is high, and the myometrium of the uterine angle is thin. It may be safer to terminate these pregnancies during the early stages. However, an inaccessible position of implantation may cause difficult curettage. Hysteroscopy and/or laparoscopy guided curettage, and treatment with methotrexate in early angular pregnancies are the preferred methods of treatment $(8)$.
The site of angular pregnancy could cause uterine atony during delivery due to weakness or lack of myometrial tissue and inadequate contraction, and excessive vascular development. There may even be a need for hysterectomy if accompanied by a placental adhesion anomaly. In a case of suspected retained placenta, despite manual intervention, a coronal incision can be made into the myometrium overlying the placenta. In case of excessive bleeding due to atony, a few square sutures using long absorbable sutures from anterior to posterior through the uterus in order to obliterate the asymmetrical uterine sacculation can be peformed successfully as we did in our case.

\section{Ethics}

Informed Consent: Consent form was filled out by all participants.

Peer-review: Externally peer-reviewed.

\section{Authorship Contributions}

Surgical and Medical Practices: İbrahim Alanbay, Mustafa Öztürk, Kazım Emre Karaşahin, Müfit Cemal Yenen, Concept: İbrahim Alanbay, Mustafa Öztürk, Design: İbrahim Alanbay, Mustafa Öztürk, Data Collection or Processing: İbrahim Alanbay, Analysis or Interpretation: İbrahim Alanbay, Literature Search: İbrahim Alanbay, Mustafa Öztürk, Kazım Emre Karaşahin, Writing: İbrahim Alanbay, Mustafa Öztürk, Kazım Emre Karaşahin.

Conflict of Interest: No conflict of interest was declared by the authors.

Financial Disclosure: The authors declared that this study has received no financial support.

\section{References}

1. Jansen RP, Elliott PM. Angular intrauterine pregnancy. Obstet Gynecol 1981;58:167-75.

2. HA K. Operative Gynecology. Vol II. New York, Appleton; 1898;4489.

3. Kwon JY, Hwang SJ, Shin JE, Yoon WS, Shin JC, Park IY. Two cases of angular pregnancy complicated by preterm labor and placental abruption at mid-pregnancy. J Obstet Gynaecol Res 2011;37:958-62.

4. Alves JA, Alves NG, Alencar Junior CA, Feitosa FE, da Silva Costa F. Term angular pregnancy: successful expectant management. J Obstet Gynaecol Res 2011;37:641-4.

5. Shekhar S, Verma S, Motey R, Kaushal R. Hysterotomy for retained placenta with imminent uterine rupture in a preterm angular pregnancy. Acta Obstet Gynecol Scand 2010;89:1615-6.

6. Moawad NS, Mahajan ST, Moniz MH, Taylor SE, Hurd WW. Current diagnosis and treatment of interstitial pregnancy. Am J Obstet Gynecol 2010;202:15-29.

7. Arleo EK, DeFilippis EM. Cornual, interstitial, and angular pregnancies: clarifying the terms and a review of the literature. Clin Imaging 2014;38:763-70.

8. Tarim E, Ulusan S, Kilicdag E, Yildirim T, Bagis T, Kuscu E. Angular pregnancy. J Obstet Gynaecol Res 2004;30:377-9. 